\title{
Management and Prevention of Saphenous Vein Graft Failure: A Review
}

Peter McKavanagh • Bobby Yanagawa - George Zawadowski ·

Asim Cheema

Received: May 8, 2017 / Published online: July 26, 2017

(C) The Author(s) 2017. This article is an open access publication

\section{ABSTRACT}

Coronary artery bypass grafting (CABG) remains a vital treatment for patients with multivessel coronary artery disease (CAD), especially diabetics. The long-term benefit of the internal thoracic artery graft is well established and remains the gold standard for revascularization of severe CAD. It is not always possible to achieve complete revascularization through arterial grafts, necessitating the use of saphenous vein grafts (SVG). Unfortunately, SVGs do not have the same longevity, and their failure is associated with significant adverse cardiac outcomes and mortality. This paper reviews the pathogenesis of SVG failure, highlighting the difference between early, intermediate, and late failure. It also addresses the different surgical techniques that affect the incidence of SVG failure, as well as the medical and percutaneous prevention and treatment options in contemporary practice.

Enhanced content To view enhanced content for this article go to http://www.medengine.com/Redeem/ EE98F06071990627.

P. McKavanagh ( $₫) \cdot$ B. Yanagawa .

G. Zawadowski · A. Cheema

Terrence Donnelly Heart Center, Divisions of Cardiology and Cardiac Surgery, St Michael's

Hospital, University of Toronto, Toronto, Canada

e-mail: mckavanagh@doctors.net.uk
Keywords: Anticoagulation; Antiplatelet; Graft failure; Saphenous vein graft

\section{INTRODUCTION}

Coronary artery bypass grafting (CABG) remains the gold standard treatment for revascularization of complex multivessel coronary artery disease (CAD) and has proven long-term survival benefits $[1,2]$ especially in patients with diabetes [3-5]. Despite increasing advances in percutaneous coronary intervention (PCI), over 400,000 patients per year in the US still undergo CABG [6]. The main shortcoming of CABG is saphenous vein graft (SVG) failure, which is associated with adverse cardiac events, such as recurrent angina, need for repeated coronary revascularization, myocardial infarction, and death $[7,8]$.

The use of an internal thoracic artery (ITA) graft has proven prognostic benefits [9] with its patency at 10 years having been quoted as $85-91 \%[9,10]$. In comparison, rates of SVG failure at 1-year post surgery have been quoted at between $10 \%$ and $25 \%[10,11]$. From 1 to 5 years a further $5 \%$ to $10 \%$ SVGs will close, and from years 6 to 10 an additional 20-25\% will fail, [12] meaning that at 10 years SVG patency rates are approximately $50 \%$, with only half of these atherosclerosis free [13].

Greater use of multiple arterial grafts during CABG has repeatedly been shown to improve 
event-free survival of patients undergoing multivessel coronary artery bypass grafting [14-19] including the use of the radial artery as a second arterial graft $[20,21]$. Despite this data and support from guideline recommendations, the use of multiple arterial grafts during surgical revascularization has not translated into clinical practice. Only $9 \%$ of CABG in North America is performed with multiple arterial grafting [22], meaning the SVG is still the most commonly used conduit in conventional CABG in North America. Interesting a recent RCT comparing single and bilateral internal-thoracic-artery in 3102 patients with there being no difference in mortality or the rates of cardiovascular events at 5 years of follow-up. There were more sternal wound complications with bilateral internal thoracic artery grafting than with single internal thoracic artery grafting. [23].

Treatment of occluded SVGs is challenging, and thus preventing their obstruction is of utmost importance [24]. Here we discuss the known pathogenesis of SVG failure and critically review the medical treatments for prevention of SVG failure.

This article does not contain any new studies with human or animal subjects performed by any of the authors.

\section{PATHOGENESIS}

SVG failure can be divided conceptually into three phases: early, intermediate, and late [25]. Early failure (less than 1 month) is primarily due to technical failure or thrombosis, generally at the site of anastomosis. Several predisposing factors can trigger this through graft endothelial injury. Initial harvesting of the vein disrupts the vasa vasorum and adventitia causing hypoxia in the vessel wall, promoting platelet adhesion and thrombosis [26]. Intraoperative assessment of graft integrity by high pressure distension can further stress the wall $[27,28]$ exposing the media to proinflammatory and procoagulant reactions, even before graft aortocoronary implantation $[29,30]$. Implantation exposes the vein to arterial pressure increasing venous diameter, turbulent blood flow and shear stress
[27], which further damages the endothelial layer causing decreased levels of nitric oxide, promoting vasospasm and reducing vessel patency [31].

Intermediate ( 1 month-1 year) graft failure is caused primarily by progressive neointimal hyperplasia secondary to exposure to arterial pressure and is thought to affect all SVGs to varying degrees [32]. Arterial blood flow damages the endothelium resulting in release of growth factors and cytokines causing platelets and activated macrophages migration, and proliferation of smooth muscle cells. The migrated smooth muscle cells release extracellular matrix resulting in a reduction in intimal cellularity [33]. Reduced levels of endothelial nitric oxide, prostaglandins and adenosine, further contribute to smooth muscle proliferation [34-36]. Over time continued smooth muscle cell and fibroblast migration and proliferation cause extracellular matrix deposition and fibrotic change leading to development of neointimal hyperplasia, which results in luminal loss and a predisposition towards graft atherosclerosis [37].

Late (beyond 1 year) graft failure is primarily due to progressive atherosclerosis, which occurs over the already injured endothelium. Compared to native coronary artery atheroma, SVG atherosclerosis is more diffuse and concentric, yet less calcified [25]. In addition, SVG are not capable of positive remodelling [38], meaning long-term atherosclerotic lesions are often complicated by aneurysmal dilatation and associated with risk of thrombosis [39]. SVG atherosclerosis occurs at two main sites, aorto-ostial or the main shaft of the graft, with shaft lesions associated with increased rates of death and myocardial infarction, having higher rates of plaque rupture and no-reflow [40, 41].

\section{FACTORS PREDISPOSING TO SVG FAILURE}

Factors linked to SVG failure include patient-related, graft related and surgical related. Patient-related include age, female gender, left ventricular dysfunction, renal insufficiency, 
diabetes, as well as atherosclerotic risk factors $[13,42-45]$. The graft-related factors include the coronary flow and the specific artery grafted. Reduced flow has been associated with greater neointimal proliferation in SVG and failure [46] and is dependent on inflow, graft diameter, presence of any focal stenoses and the size of the distal perfusion bed. SVGs to the left anterior descending artery have the best patency, followed by those to diagonals, circumflex branches, and the posterior descending artery, with grafts to the main right coronary artery least likely to have long term patency $[47,48]$.

Surgical factors that predispose patients to thrombosis include graft kinking, size mismatch between the graft and artery, poor distal runoff, and small target vessel diameter. Several surgical techniques have been shown to influence SVG patency.

\section{No Touch Technique}

Intra-operative manual disruption, as well as the use of hydrostatic dilatation can promote endothelium thrombus within the graft [49]. Souza et al. in 1996 developed the "no-touch" SVG harvesting, which involved removing the pedicled SVG with the perivascular tissue intact, thus avoiding direct contact and thus manual distension of the vein. This demonstrated improved graft patency and less neointimal hyperplasia compared with the standard harvesting technique [50, 51]. More recent randomised work has suggested that compared with conventional harvesting, the use of no touch harvesting, results in less intra-operative vascular smooth muscle cell activation, suggesting less likelihood of developing neointimal hyperplasia [52]. Other studies have even suggested that the use of no touch harvesting confers a significantly higher long term ( $>15$ years) patency than conventional technique [53].

\section{On-Pump and Off-Pump Surgery}

A number of studies have compared on-pump and off-pump CABG in terms of clinical outcomes and graft patency. Off-pump CABG involves surgery without a heart-lung machine or cardioplegia. In contrast during on-pump surgery the heart is motionless and empty, and the veins are unpressurized and contracted, which may create a more favourable condition for vascular anastomoses. Although several small initial studies found that after 1 year there was no difference in graft patency or clinical outcomes [54-57], the larger randomized on/off bypass (ROOBY) trial suggested the off-pump group had worse 1-year composite outcomes $(9.9 \%$ vs. $7.4 \%, P=0.04)$ and poorer graft patency ( $82.6 \%$ vs. $87.8 \%, P<0.01$ ) [58]. These results have also been reported in other randomized studies $[59,60]$, as well as meta-analyses $[61,62]$. The poorer graft patency rates in off pump CABG could be explained by a relative hypercoaguability compared with on-pump surgery, as cardiopulmonary bypass induces platelet dysfunction and coagulopathy which may be desirable in promoting SVG patency. Mannacio et al. conducted a single-centre prospective RCT study which randomized 300 patients undergoing off-pump CABG to either aspirin $100 \mathrm{mg}(n=150)$ or aspirin $100 \mathrm{mg}$ plus clopidogrel $(n=150)$. Graft patency was assessed by CTA. DAPT use was associated with a reduced SVG occlusion rate $(7.4 \%$ vs. $13.1 \%$; $P=0.04$ ) [115]. Current guidelines recommend 1 year of DAPT after off pump CABG to improve SVG patency [170].

\section{Sequential and Composite Grafting}

The most basic SVG configuration is a single graft, which is composed of a single distal anastomosis for every proximal anastomosis. In contrast, sequential and composite grafting involves more than one distal anastomosis for every proximal anastomosis allowing for more complete revascularisation. The sequential anastomosis was first described by both Flemma and Bartley $[63,64]$ which, was initially termed the "snake" operation [65] with longitudinal side-to-side "snaking" grafts between recipient arteries. The major advantage of the sequential anastomosis is the larger combined perfusion bed resulting in lower coronary vascular resistance and thus higher flow velocity compared 
to single grafts $[65,66]$. The composite graft has either a Y- or T-end-to-side graft constructed to allow perfusion of more than one distal target using a single graft. Composite grafts were first described in arterial grafts [67], but may also be constructed with SVG. The composite graft anastomosis must be performed accurately as an error can potentially threaten both distal outflows. Furthermore, there is risk of steal from one territory to another in the case of unbalanced flows.

The use of grafts with multiple distal anastomoses allows for a more complete revascularization in patients with multi-vessel CAD by using the limited SVG material more efficiently. Initially the use of multiple distal target SVGs was met with optimism, with early data suggesting that clinical outcomes were comparable or better than single distal target SVGs $[63,65,66]$. However, more recent larger data has suggested that patients who received a composite SVG were more likely to have graft failure and had a trend towards increased death, MI, or repeat revascularization in the 5 years after surgery [68]. This is particularly true in diabetics where both the end-to-side and side-to-side anastomosis may insert into a poor-quality target vessel $[69,70]$.

\section{Compression Therapy}

The luminal diameter of SVG are generally much larger than the coronary artery to which they insert, potentially creating a mismatch in blood flow. This can result in stasis and abnormal flow currents within the vein, damaging the vessel and potentially leading to thrombus formation. In addition, because veins lack the muscular wall that is seen in arteries, exposure to arterial pressure damages SVG resulting in further dilation and neointimal hyperplasia. External compression of SVGs prevents dilation and promotes down-sizing, which has been shown to encourage more arterial like healing and help reduce intimal hyperplasia [71, 72]. External compression can be achieved by a support device implanted during surgery. The eSVS $^{\circledR}$ mesh (Kips Bay Medical, Inc., Minneapolis, MN, USA) is a flexible extravascular nickel-titanium mesh, with early work suggesting that it reinforces SVGs; improving healing with less endothelial injury and neointimal hyperplasia formation compared to unsupported grafts [71, 72]. Recent non-randomised studies have suggested a clinical benefit. Genoni et al. reported safe application of the device in 20 patients who received the mesh supporting the SVG to the right coronary artery only. The patency of the grafts was assessed after 5 days by computerized tomography angiography (CTA), with a 95\% success rate [73]. Klima et al. reported the 7-month follow-up in 12 patients who received an on-pump non-sequential eSVS $^{\circledR}$ mesh. The CTA patency rate was $92 \%$ [74]. Inderbitzin et al. reported the 1-year follow-up in 19 of 22 surviving patients who had received the mesh with overall 1-year CTA patency rate of $21 \mathrm{eSVS}^{\circledR}$ meshed SVGs being $76 \%$ [75]. Larger randomised studies with longer term follow-up are needed however before more widespread clinical adoption of such devices.

\section{ASSESSMENT FOR SVG PATENCY}

Routine assessment for SVG failure is not recommended by current guidelines, and thus rates of occlusion are only studied in clinical trials or in clinically driven follow-up. Assessment of SVG patency is generally performed via invasive coronary angiography (ICA), which in addition to being more technically difficult compared to native coronaries, also has rates of complications three times higher [76]. More recently, the use of coronary CTA has shown much promise in this regard (Fig. 1). Studies from over a decade ago show that evaluation of coronary bypass grafts by CTA is highly accurate in predicting the findings seen on ICA [77-80] with a meta-analysis, of 16- and 64-slice CTAs quoting a sensitivity of $98 \%$ and specificity of $97 \%$ for graft stenosis or occlusion [81]. Newer generation of CT scanners undoubtedly increase diagnostic accuracy, with the use of CTA for post CABG assessment now recommended in clinical guidelines [82]. Limitations of CTA assessment including artifact from surgical clips and difficulty in assessing distal anastomoses 


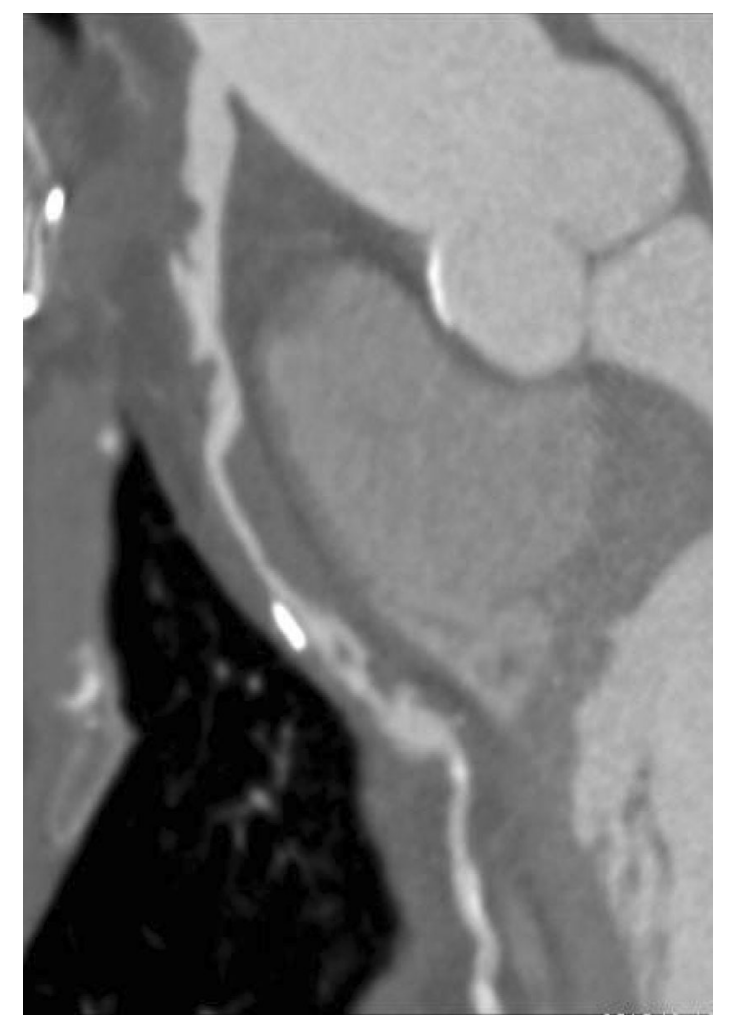

Fig. 1 Spiral thrombus within SVG graft

inserted into heavily calcified native vessels [83].

\section{MEDICAL MANAGEMENT FOR PREVENTION OF SVG FAILURE}

Hypercoagulable states post CABG increase thrombosis and lower overall graft patency rates [84], thus necessitating the need for therapy aimed at reducing thrombotic risk. There have been several studies that have assessed the use of various pharmacologic agents.

\section{Aspirin}

Very early studies assessing the use of aspirin (acetylsalicylic acid) for SVG patency were not encouraging. Pantley et al. in 1979 assessed 50 patients who were randomized to 24 controls, 13 receiving dual antiplatelet therapy (DAPT) with aspirin and dipyridamole, and 13 receiving warfarin [85]. Treatment began on the third post-operative day. Six months after surgery, all patients underwent ICA to assess graft patency. Twenty-seven of 33 grafts (82\%) with DAPT and 29 of 37 grafts $(78 \%)$ with warfarin $(P<0.5)$ were patent. The overall conclusion was that postoperative treatment either with DAPT or with warfarin failed to improve the patency. McEnany et al. in 1982 randomized trial compared warfarin, aspirin, and placebo treatment in post-CABG patients [86]. From an initial group of 216 patients, SVG patency was determined in 111 patients (220 grafts) from 1 to 47 months postoperatively. There was a trend toward better cumulative graft patency in patients given warfarin, but the results did not achieve statistical significance. In 1984 Chesebro et al. compared the combination of aspirin and dipyridamole to placebo in 407 patients with treatment beginning as early as $7 \mathrm{~h}$ post-surgery [87]. ICA at 1 month showed SVG patency significantly higher in the antiplatelet therapy cohort $(98 \%$ vs. $90 \%$, aspirin and dipyridamole vs placebo; $P<0.0001$ ). Longer term follow-up of the same study also showed a significant difference in patency (89\% vs. $77 \%$, aspirin and dipyridamole vs placebo; $P<0.0001)$, suggesting that DAPT prevented late SVG occlusions in those patients whose grafts had been patent at 1 month (6\% vs. $14 \%$ late occlusion rate, aspirin and dipyridamole vs. placebo; $P=0.02$ ) [32]. The Veterans Administration Cooperative Study compared the use of different aspirin regimens in 772 CABG patients [88]. They administered either (1) aspirin, $325 \mathrm{mg}$ daily, (2) aspirin, $325 \mathrm{mg}$ three times daily, (3) aspirin plus dipyridamole (325 $\mathrm{mg}$ and $75 \mathrm{mg}$, three times daily), (4) sulfinpyrazone (267 mg three times daily), or (5) placebo (three times daily). Medications were taken to for 1 year. At 60 days post-surgery, 555 patients (1781 grafts) had undergone ICA, illustrating the following graft patency rates: aspirin once daily 93.5\%; aspirin three times daily 92.3\%; aspirin and dipyridamole three times daily 91.9\%; sulfinpyrazone 90.2\%. All aspirin-containing therapeutic regimens improved $(P<0.05)$ graft patency compared with placebo $(85.2 \%)$. Operative mortality was $2.3 \%$, without significant differences among treatment groups. Overall conclusions were early SVG patency was 
improved after CABG with all aspirin-containing drug regimens.

In addition to graft patency, the use of aspirin has also been shown to reduce in-hospital mortality without an associated increase in hemorrhage-related risks [89-91]. Consequently, its use before CABG surgery is recommended in both European and American Guidelines [92, 93].

\section{Clopidogrel}

Clopidogrel is a thienopyridine-class antiplatelet that inhibits the platelet $\mathrm{P}_{2} \mathrm{Y}_{12}$ adenosine diphosphate receptor and has been the mainstay of DAPT therapy for over 10 years. The benefit of DAPT in acute coronary syndrome (ACS) is well established [100-102], with National guidelines recommend their use on presentation [99, 103, 104, 107]. This has been reflected in clinical practice with the Global Registry of Acute Coronary Events (GRACE) and GRACE2 registries reporting a significant increase in early use in patients with ACS $[94,105,106]$. This is despite the fact that $7-11 \%$ of ACS patients will subsequently require CABG [94, 95] and pre-surgery use of DAPT is associated with increased risk of postoperative death, reoperations for bleeding, blood loss, and need of blood transfusions [96]. Consequently, for ACS patients who subsequently need CABG, it is recommended to stop the second antiplatelet agent 5-7 days prior to CABG if possible [97-99]. It is recommended that DAPT should be restarted after CABG when safe $[99,104,107]$. However, the risk of bleeding remains, leading to variability in DAPT resumption post CABG [108-110].

There is a paucity of evidence in the literature directly comparing aspirin alone to DAPT with clopidogrel to improve SVG patency. Gao et al. [111] used a weekly alternating scheme in a prospective non-randomized cohort, and assigned 102 patients to clopidogrel $75 \mathrm{mg}$ daily and 95 patients to clopidogrel $75 \mathrm{mg}$ plus aspirin $100 \mathrm{mg}$ daily after CABG. No significant difference in SVG patency as assessed by CTA was seen at 1 month or 1 year (1 month: $98.1 \%$ vs. $98.2 \%, P=0.73$; 1 year: $93.5 \%$ vs. $96.3 \%$,
$P=0.25$, clopidogrel vs. clopidogrel plus aspirin). Sun et al. used partial blinding to compare postoperative clopidogrel $75 \mathrm{mg}$ and aspirin $81 \mathrm{mg}$ daily with aspirin $81 \mathrm{mg}$ alone among 100 patients undergoing on-pump CABG [112]. Graft patency was assessed by CTA, for 79 patients at 1 month. There was no difference in SVG patency either among all grafts (92.9\% vs. $95 \%$, aspirin vs aspirin and clopidogrel; $P=0.43)$ or SVG alone $(93.2 \%$ vs. $93.5 \%$, aspirin vs. aspirin and clopidogrel; $P=0.92$ ). Gao et al. in a RCT randomized 249 patients to either clopidogrel $75 \mathrm{mg}$ plus aspirin $100 \mathrm{mg}$ daily or aspirin $100 \mathrm{mg}$ alone starting within $48 \mathrm{~h}$ of surgery [113]. No blinding or placebo control was used in this trial. SVG patency by CTA was assessed in $90 \%$ of patients at 3 months, with patency higher in the DAPT group compared to aspirin alone $(85.7 \%$ vs. $91.6 \%, P=0.04)$. The Clopidogrel After Surgery for Coronary Artery Disease (CASCADE) trial was a randomized, double-blind, placebo-controlled trial comparing aspirin $162 \mathrm{mg}$ alone with DAPT using aspirin $162 \mathrm{mg}$ and clopidogrel $75 \mathrm{mg}$ [114]. The 113 patients underwent ICA and intravascular ultrasound (IVUS) at 1 year after surgery to assess for intimal hyperplasia. The use of DAPT did not significantly reduce the development of intimal hyperplasia compared with aspirin alone. Overall graft patency $(95.2 \%$ vs. $95.5 \%$, DAPT vs. aspirin alone; $P=0.90)$ and SVG patency $(94.3 \%$ vs. $93.2 \%, P=0.69)$ were not significantly different. Mannacio et al. conducted a single-centre prospective RCT study which randomized 300 patients undergoing off-pump CABG to either aspirin $100 \mathrm{mg}(n=150)$ or aspirin $100 \mathrm{mg}$ plus clopidogrel $(n=150)$. Graft patency was assessed by CTA. DAPT use was associated with a reduced SVG occlusion rate $(7.4 \%$ vs. $13.1 \%$; $P=0.04$ ) [115]. In 2017 Rafiq et al. reported a randomized trial comparing DAPT to aspirin monotherapy in hypercoaguable patients undergoing $\mathrm{CABG}$ and found no difference in SVG patency rates at 3 months [116] Based on this evidence current guidelines recommend 1 year of DAPT after CABG in patients presenting with ACS or who undergo off pump surgery, however the benefits of routine DAPT after CABG have not been well established [117]. 


\section{Anticoagulant Therapy}

Little is known about the use of an oral anticoagulant to prevent SVG failure and improving clinical outcomes. It has been suggested that patients taking warfarin who undergo CABG have no higher rate of bleeding compared to controls, [118] and warfarin administration concomitantly with an antiplatelet agent dramatically reduces the incidence of ischemic stroke associated with postoperative atrial fibrillation [119]. Most trials assessing the use of anticoagulants to prevent SVG failure in CABG are old, have small numbers and were in direct comparison to antiplatelet therapy [85, 86, 120-122]. However, Gohlke et al. [123] randomized 89 patients to a vitamin $\mathrm{K}$ antagonist, (starting on the seventh postoperative day) and 84 patients to no anticoagulation. ICA follow-up found graft patency after surgery was $90.4 \%$ in the treatment group and $84.6 \%$ in the control group $(P<0.015)$. The Post Coronary Artery Bypass Graft Trial was a two-by-two factorial design which assigned 1351 CABG patients to aggressive or moderate treatment to lower LDL cholesterol levels and to treatment with warfarin or placebo [124]. Angiographic follow up at 4 years showed no improvement in graft patency between the warfarin and placebo groups, although aggressive lowering of cholesterol did reduce the progression of atherosclerosis. Other trials also did not show any clinical advantage of warfarin over antiplatelets [125] and consequently the use of anticoagulants post CABG is not supported in guidelines [117] (Table 1).

\section{Ticagrelor/Prasugrel}

The evidence supporting newer, more potent antiplatelet agents comes from two main studies, PLATO and TRITON-TIMI $38[102,126]$. The PLATO study was a large randomized trial comparing DAPT with ticagrelor as opposed to clopidogrel, concluding that in ACS patients, ticagrelor significantly improved clinical outcomes without an increase in the rate of overall major bleeding [102]. In PLATO, 1584 patients (12\%) underwent CABG. "Major Fatal/
Life-Threatening" bleeding was approximately $42 \%$ in both treatment groups. Fatal CABG bleeding occurred uncommonly, six patients in each treatment group $(0.8 \%$ and $0.7 \%$ of CABG patients on ticagrelor and clopidogrel, respectively). Further subgroup-analysis in the PLATO study showed that the use of ticagrelor compared to clopidogrel was associated with better clinical outcomes both in ACS patients with prior CABG and those who underwent redo CABG [102, 127, 128]. In TRITON-TIMI 38 patients that underwent CABG after presenting with ACS also had a significantly reduced all-cause mortality with prasugrel compared with clopidogrel $(2.31 \%$ vs. $8.67 \%$ adjusted odds ratio: $0.26 ; P=0.025$ ) in the short term, although there was an increase in observed bleeding, platelet transfusion, and surgical re-exploration for bleeding in patients randomized to receive prasugrel [126]. A recent retrospective observational study compared the use of dual antiplatelet therapy with aspirin and ticagrelor $(n=1266)$ or clopidogrel $(n=978)$ in ACS patients who underwent CABG [129]. The incidence of CABG-related major bleeding was high when ticagrelor/clopidogrel was discontinued $<24 \mathrm{~h}$ before surgery. Discontinuation 3 days before surgery, as opposed to 5 days, did not increase the incidence of major bleeding complications with ticagrelor, but increased the risk with clopidogrel. The overall risk of major CABG-related bleeding complications was lower with ticagrelor than with clopidogrel [12.9 vs. $17.6 \%$, adjusted OR 0.72 (95\% CI 0.56-0.92), $P=0.012]$. Based on these data current guidelines support DAPT after CABG in patients presenting with ACS with either clopidogrel, prasugrel or ticagrelor (preferred over clopidogrel) [117].

\section{Lipid Lowering Therapy}

As with native coronary arteries, SVG atherosclerosis correlates with serum lipid levels with the use of statins seemingly slowing disease progression. The lipid lowering aspect of the Post Coronary Artery Bypass Trial involved randomization to either aggressive or moderate cholesterol management [123]. ICA at 4 years 
Table 1 Medical intervention for SVG patency

\begin{tabular}{|c|c|c|c|}
\hline Author & Comparison & Design & Result \\
\hline \multicolumn{4}{|l|}{ Anticoagulant vs antiplatelet } \\
\hline Pantely et al. (1979) [85] & $\begin{array}{l}\text { Aspirin/dipyridamole } \\
\text { vs. oral anticoagulant }\end{array}$ & $\begin{array}{l}\text { Randomised. SVG patency } \\
\text { assessed by ICA }\end{array}$ & No difference in graft patency \\
\hline $\begin{array}{l}\text { McEnany et al. (1982) } \\
{[86]}\end{array}$ & $\begin{array}{l}\text { Aspirin vs. oral } \\
\text { anticoagulant vs. } \\
\text { placebo }\end{array}$ & $\begin{array}{l}\text { Randomised. SVG patency } \\
\text { assessed by ICA }\end{array}$ & No difference in graft patency \\
\hline $\begin{array}{l}\text { van der Meer et al. (1993) } \\
\text { [122] }\end{array}$ & $\begin{array}{l}\text { Aspirin vs. aspirin/ } \\
\text { dipyridamole vs. oral } \\
\text { anticoagulant }\end{array}$ & $\begin{array}{l}\text { Randomised. SVG patency } \\
\text { assessed by ICA }\end{array}$ & No difference in graft patency \\
\hline \multicolumn{4}{|l|}{ Anticoagulant vs placebo } \\
\hline $\begin{array}{l}\text { Gohlke et al. (1981) } \\
\text { [123] }\end{array}$ & $\begin{array}{l}\text { Phenoprocoumon vs. } \\
\text { placebo }\end{array}$ & $\begin{array}{l}\text { Randomised. SVG patency } \\
\text { assessed by ICA }\end{array}$ & $\begin{array}{l}\text { Higher patency rates with oral } \\
\text { anticoagulant }\end{array}$ \\
\hline $\begin{array}{l}\text { Post Coronary Artery } \\
\text { Bypass Graft Trial } \\
\text { Investigators. (1997) } \\
{[124]}\end{array}$ & Wafarin vs. placebo & $\begin{array}{l}2 \times 2 \text { multifactorial. } \\
\text { Randomised. SVG patency } \\
\text { assessed by ICA }\end{array}$ & $\begin{array}{l}\text { Warfarin did not reduce the } \\
\text { progression of atherosclerosis } \\
\text { in SVGs }\end{array}$ \\
\hline \multicolumn{4}{|l|}{ Antiplatelet vs placebo } \\
\hline $\begin{array}{l}\text { Chesebro et al. (1984) } \\
\text { [32] }\end{array}$ & $\begin{array}{l}\text { Aspirin/dipyridamole } \\
\text { vs. placebo }\end{array}$ & $\begin{array}{l}\text { Randomised. SVG patency } \\
\text { assessed by ICA }\end{array}$ & $\begin{array}{l}\text { Higher patency rates with } \\
\text { DAPT }\end{array}$ \\
\hline $\begin{array}{l}\text { Goldman et al. (1989) } \\
\text { [88] }\end{array}$ & $\begin{array}{l}\text { Aspirin vs. aspirin/ } \\
\text { dipyridamole vs } \\
\text { sulfinpyrazone vs } \\
\text { placebo }\end{array}$ & $\begin{array}{l}\text { Randomised. SVG patency } \\
\text { assessed by ICA }\end{array}$ & $\begin{array}{l}\text { Higher patency rates with } \\
\text { aspirin }\end{array}$ \\
\hline \multicolumn{4}{|c|}{ Aspirin vs DAPT with clopidogrel } \\
\hline Gao et al. (2009) [111] & $\begin{array}{l}\text { Clopidogrel vs. } \\
\text { aspirin/clopidogrel }\end{array}$ & $\begin{array}{l}\text { Non randomised. SVG patency } \\
\text { assessed by CTA }\end{array}$ & No difference in graft patency \\
\hline Kulik et al. (2010) [114] & $\begin{array}{l}\text { Aspirin vs. } \\
\text { aspirin/clopidogrel }\end{array}$ & $\begin{array}{l}\text { Randomised. SVG patency } \\
\text { assessed by ICA }\end{array}$ & No differences \\
\hline Gao et al. (2010) [113] & $\begin{array}{l}\text { Aspirin vs. } \\
\text { aspirin/clopidogrel }\end{array}$ & $\begin{array}{l}\text { Randomised. SVG patency } \\
\text { assessed by CTA }\end{array}$ & $\begin{array}{l}\text { Higher patency rates with } \\
\text { DAPT }\end{array}$ \\
\hline Sun et al. (2010) [112] & $\begin{array}{l}\text { Aspirin vs. } \\
\text { aspirin/clopidogrel }\end{array}$ & $\begin{array}{l}\text { Randomised. SVG patency } \\
\text { assessed by CTA }\end{array}$ & $\begin{array}{l}\text { Higher patency rates with } \\
\text { DAPT }\end{array}$ \\
\hline $\begin{array}{l}\text { Mannacio et al. (2012) } \\
\text { [115] }\end{array}$ & $\begin{array}{l}\text { Aspirin vs. } \\
\text { aspirin/clopidogrel in } \\
\text { off pump CABG }\end{array}$ & $\begin{array}{l}\text { Randomised. SVG patency } \\
\text { assessed by CTA }\end{array}$ & $\begin{array}{l}\text { Higher patency rates with } \\
\text { DAPT }\end{array}$ \\
\hline Aspirin vs. DAPT with ne & antiplatelets ${ }^{\mathrm{a}}$ & & \\
\hline
\end{tabular}


Table 1 continued

\begin{tabular}{|c|c|c|c|}
\hline Author & Comparison & Design & Result \\
\hline Held et al. (2011) [127] & $\begin{array}{l}\text { Aspirin and clopidogrel } \\
\text { vs. aspirin and } \\
\text { ticagrelor }\end{array}$ & $\begin{array}{l}\text { CABG subgroup of PLATO trial } \\
\text { to assess bleeding and clinical } \\
\text { outcomes }\end{array}$ & $\begin{array}{l}\text { Reduction in total and CV } \\
\text { mortality without excess risk } \\
\text { of bleeding with ticagrelor }\end{array}$ \\
\hline Smith et al. (2012) [126] & $\begin{array}{l}\text { Aspirin and clopidogrel } \\
\text { vs. aspirin and } \\
\text { prasugrel }\end{array}$ & $\begin{array}{l}\text { CABG subgroup of TRITON } \\
\text { TIMI-38 trial to assess } \\
\text { bleeding and clinical outcomes }\end{array}$ & $\begin{array}{l}\text { Higher bleeding but lower rate } \\
\text { of death with prasugrel }\end{array}$ \\
\hline $\begin{array}{l}\text { Hansson et al. (2016) } \\
\text { [129] }\end{array}$ & $\begin{array}{l}\text { Aspirin and clopidogrel } \\
\text { vs. aspirin and } \\
\text { ticagrelor }\end{array}$ & $\begin{array}{l}\text { Retrospective observational to } \\
\text { assess bleeding }\end{array}$ & $\begin{array}{l}\text { Lower bleeding complications } \\
\text { with ticagrelor }\end{array}$ \\
\hline \multicolumn{4}{|l|}{ Lipid lowering therapy } \\
\hline $\begin{array}{l}\text { Post Coronary Artery } \\
\text { Bypass Graft Trial } \\
\text { Investigators. (1997) } \\
{[124]}\end{array}$ & $\begin{array}{c}\text { Lovastatin } 2.5-5 \mathrm{mg} \text { vs. } \\
\text { lovastatin } 40-80 \mathrm{mg}\end{array}$ & $\begin{array}{l}2 \times 2 \text { multifactorial RCT to } \\
\text { assess SVG patency with angio }\end{array}$ & $\begin{array}{l}\text { Higher patency rates with higher } \\
\text { statins }\end{array}$ \\
\hline $\begin{array}{l}\text { Makuuchi et al. (2005) } \\
\text { [131] }\end{array}$ & Pravastatin vs. placebo & $\begin{array}{l}\text { Randomised. SVG patency } \\
\text { assessed by ICA }\end{array}$ & $\begin{array}{l}\text { Higher patency rates with higher } \\
\text { statins }\end{array}$ \\
\hline Kulik et al. (2011) [132] & $\begin{array}{l}\text { LDL levels }<100 \mathrm{mg} / \\
\text { dL compared to levels } \\
>100 \mathrm{mg} / \mathrm{dL}\end{array}$ & $\begin{array}{l}\text { Non-randomised post hoc } \\
\text { analysis of statin use in } \\
\text { CASCADE trial }\end{array}$ & $\begin{array}{l}\text { Higher patency rates with LDL } \\
\quad<100 \mathrm{mg} / \mathrm{dL}\end{array}$ \\
\hline
\end{tabular}

a Clinical studies only-none on SVG patency

highlighted that aggressive cholesterol treatment improved SVG patency (occlusion rates of $10 \%$ vs. $21 \%, P<0.0001)$. Longer term follow up showed aggressive management was associated with a significant reduction in repeat revascularization and adverse cardiovascular events [130]. Makuuchi et al. randomly assigned 303 post CABG patients to either pravastatin or control. ICA were obtained at baseline and at the end of 5-year follow-up in 182 (60\%) patients [131]. Although there was no significant difference in the quantitative ICA measurements between the two groups, a global change score indicated a significant pravastatin-mediated reduction in plaque progression $(P<0.01)$. A post hoc analysis of The CASCADE study assessed the impact of statin therapy on graft patency and neointimal hyperplasia, comparing these to different levels of LDL [132]. Twelve-month graft patency was higher for patients with LDL levels $<100 \mathrm{mg} / \mathrm{dL}(96.5 \%)$ compared with levels $>100 \mathrm{mg} / \mathrm{dL} \quad(83.3 \%$, $P=0.03)$. However, no improvement in graft patency was noted with further LDL reduction to less than $70 \mathrm{mg} / \mathrm{dL}(P=1.00)$. In addition, consistent statin use throughout the trial period was independently associated with less SVG neointimal hyperplasia documented by IVUS at 12 months $(P=0.04)$.

A recent meta-analysis of eight studies and 6645 patients post CABG showed that aggressive statin therapy, compared to moderate statin therapy, decreased graft atherosclerotic progression by $39 \%$ with associated clinical benefits of reduced myocardial infarction [95\% CI 0.66-0.95; risk ratio $(\mathrm{RR})=0.80$; and $95 \% \mathrm{CI}$ $0.66-0.85 ; \mathrm{RR}=0.75]$ and lower risk of cardiac death (95\% CI 0.64-1.08; RR=0.83) [133]. Other lipid lowering drugs have also been shown to have clinical benefits post CABG 
[134-137]. However, statins have both cholesterol lowering and anti-inflammatory properties. Their anti-inflammatory effect reduces vascular oxidative stress and improves nitric oxide bioavailability, thus reducing vascular thrombosis and improving SVG patency [138-140]. In addition, hyperlipidemia has also been identified as one of the most potent risks of increasing intimal proliferation and subsequent fibrous hyperplasia [8]. As such the early use of statins is recommended in all CABG patients unless contraindicated [141].

\section{Gene Therapy}

Gene therapy in a relatively new approach to preventing SVG failure and its use is still in the developmental stage. The aim is to inhibit the cellular proliferation that causes intimal hyperplasia thus preventing SVG failure. Bypass grafting presents an ideal opportunity for gene therapy, as SVGs can be treated ex vivo, thus maximizing gene delivery, minimizing the potential for systemic toxicity, and targeting the pathogenesis of vein graft disease at its onset [142]. Initial optimism was seen after PREVENT II, a phase IIb trial of 200 patients undergoing CABG, randomized patients to either placebo or edifoligide, a transcription factor decoy that modulates smooth muscle cell proliferation. The treatment group demonstrated a 30\% relative reduction in SVG critical stenosis by ICA and a 30\% reduction in total wall volume by intravascular ultrasound [143]. This was then followed by the much larger trial PREVENT IV in which 3014 patients undergoing CABG were enrolled [144]. Harvested SVG were randomly assigned to ex vivo treatment with edifoligide, or saline solution placebo before grafting. At follow-up ICA 12-18 months after the operation, there was no difference in the rate of graft occlusion ( $41.8 \%$ in the edifoligide group vs. $41.7 \%$ in the placebo group; $P=0.97$ ) or the primary end-point of death and SVG occlusion, or the composite clinical end-point of death, MI or revascularization. Currently gene therapy remains an area of research, but has no role in improving SVG patency.

\section{INTERVENTION FOR GRAFT FAILURE}

PCI on CABG grafts comprises an important subset of interventional cardiology cases, with approximately $5.7 \%$ of all PCIs between 2004 and 2009 being SVG PCI [145]. Initial early studies of plain old balloon angioplasty (POBA) on SVGs revealed disheartening results with $46-60 \%$ restenosis rates in the first 6 months [146]. The seminal study comparing POBA with bare-metal stents (BMS) was the Saphenous Vein De Novo (SAVED) trial, which compared POBA with BMS in SVG lesions [147]. This demonstrated a higher procedural success rates (97\% vs. $86 \%$ ) with BMS and a better composite outcome of freedom from death, MI, repeat CABG, and target lesion revascularization (TLR) $(26 \%$ vs. $39 \%)$. Similar work also confirmed clinical benefits of BMS compared to POBA with a reduced need for revascularization and significantly higher event-free survival at 1-year follow-up [148]. When drug eluting stents (DES) became available they were also compared to BMS in SVG PCI. The Reduction of Restenosis in Saphenous Vein Grafts With Cypher Sirolimus-Eluting Stent (RRISC) trial randomized 75 patients to either sirolimus-eluting stent or BMS, with a 6 months follow-up [149]. The instent late loss and target lesion revascularization rate was significantly reduced $(5.3 \%$ vs. $21.6 \%)$, but there was no difference in death or infarction. The Stenting of Saphenous Vein Grafts (SOS) trial randomized patients to either paclitaxel-eluting stent or BMS and found a significant reduction in the primary end-point, angiographic restenosis at 12 months (9\% vs. $51 \%$ ) as well as target lesion revascularization target vessel failure, with a trend towards lower mortality ( $5 \%$ vs. $12 \%$, hazard ratio: $1.56 ; 95 \%$ CI $0.72-4.11, \quad P=0.27) \quad[147,150]$. The Prospective, Randomized Trial of Drug-Eluting Stents Versus Bare Metal Stents for the Reduction of Restenosis in Bypass Grafts (ISAR-CABG) randomized 610 patients with diseased SVGs to DES or BMS, finding that there was a lower rate of the primary endpoint (combined incidence of death, MI, and target lesion revascularisation at 1 year) with DES, driven mostly by reduction in target lesion revascularization $(7.2 \%$ vs. 
13.1\%), with no differences in mortality [151]. This theme of improved efficacy with DES over BMS, but without mortality benefit has been also published in meta-analyses, [152, 153] and in real-world situations $[154,155]$. The introduction of 2nd generation DES compared to 1st generation, has also not improved mortality outcomes [156-158] but longer term follow up from larger studies is needed.

After graft failure redo CABG is another revascularization option, although it is associated with substantial risk. Such patients are older, have more comorbidities, more extensive $\mathrm{CAD}$, and reentry of the sternum can be problematic when patent grafts, the aorta, or the right ventricle have adhered to the sternum [159]. It is associated with higher mortality compared with primary CABG, with intraoperative mortality rates are $5.8-9.6 \%$ [160]. Other major complications quoted include stroke (1.4-3.2\%), non-fatal MI (3.0-9.6\%), and post-operative bleeding (2.7-4.4\%) [160, 161].

Patients with prior CABG presenting with ACS have a worse prognosis compared to those without [162-164]. Medical management of such patients has also been showed to be inferior to PCI $[165,166]$. Studies comparing redo CABG and PCI are limited. Early work suggested that the use of POBA vs. redo CABG had equivalent 1 and 6 year mortality rates, although POBA had higher a revascularization need [167]. The AWESOME trial randomized ischemic patients with prior history of CABG to redo $\mathrm{CABG}$ or PCI finding that in hospital mortality was significantly higher in the CABG arm [168, 169]. Retrospective observational studies have suggested long term mortality of redo CABG vs PCI is similar [170-172] although this data does not account for contemporary PCI practice.

\section{HYBRID REVASCULARIZATION}

Noting the superior patency rates of internal mammary arterial grafts compared to SVG, as well as the possibility of performing LIMA-LAD bypass grafting via a minimally invasive approach, some investigators have hypothesized that a hybrid revascularization strategy involving contemporary coronary stents as well as a LIMA graft may be superior to conventional CABG. Several reports involving small series of patients have been published $[173,174]$. The largest of these was a single center experience of 117 patients which reported 1 year freedom from major adverse events of $85.5 \%$ [175]. To date, no randomized controlled trial has been performed comparing hybrid revascularization to conventional CABG.

\section{CONCLUSIONS}

CABG remains a vital treatment for patients with multivessel CAD, especially in diabetics. Unfortunately, SVG failure limits the long-term benefits of the procedure. In this paper, we review the pathogenesis of and the differences between early, intermediate and late SVG failure. We also address the different surgical techniques and medical options used to preventing neointimal hyperplasia and SVG failure, as well as reviewing the literature regarding novel treatments and PCI in SVGs. Prevention of SVG failure is multifactorial and begins from the moment the grafts have been harvested. It is important for all physicians to recognize the impermanence of SVG and appropriate medical management is essential in maintaining graft patency.

\section{ACKNOWLEDGMENTS}

No funding or sponsorship was received for this study or publication of this article. The article processing charges were funded by the authors. All named authors meet the International Committee of Medical Journal Editors (ICMJE) criteria for authorship for this manuscript, take responsibility for the integrity of the work as a whole, and have given final approval for the version to be published.

Disclosures Peter McKavanagh, MMedSc, Bobby Yanagawa, George Zawadowski and Asim Cheema have nothing to disclose. 
Compliance with ethics guidelines This article does not contain any new studies with human or animal subjects performed by any of the authors.

Open Access. This article is distributed under the terms of the Creative Commons Attribution-NonCommercial 4.0 International License (http://creativecommons.org/licenses/by-nc/4. $0 /$ ), which permits any noncommercial use, distribution, and reproduction in any medium, provided you give appropriate credit to the original author(s) and the source, provide a link to the Creative Commons license, and indicate if changes were made.

\section{REFERENCES}

1. Yusuf S, Zucker D, Peduzzi P, Fisher LD, Takaro T, Kennedy JW, Davis K, Killip T, Passamani E, Norris R. Effect of coronary artery bypass graft surgery on survival: overview of 10-year results from randomised trials by the Coronary Artery Bypass Graft Surgery Trialists Collaboration. Lancet. 1994;344:563-70.

2. Davis KB, Chaitman B, Ryan T, Bittner V, Kennedy JW. Comparison of 15-year survival for men and women after initial medical or surgical treatment for coronary artery disease. J Am Coll Cardiol. 1995;25:1000-9.

3. Banning AP, Westaby S, Morice M-C, Kappetein AP, Mohr FW, Berti S, et al. Diabetic and nondiabetic patients with left main and/or 3-vessel coronary artery disease: comparison of outcomes with cardiac surgery and paclitaxel-eluting stents. J Am Coll Cardiol. 2010;55:1067-75.

4. Dangas GD, Farkouh ME, Sleeper LA, Yang M, Schoos MM, Macaya C, Abizaid A, Buller CE, Devlin G, Rodriguez AE, Lansky AJ, Siami FS, Domanski M, Fuster V, FREEDOM Investigators. Long-term outcome of PCI versus CABG in insulin and non-insulin-treated diabetic patients: results from the FREEDOM trial. J Am Coll Cardiol. 2014;64(12):1189-97.

5. BARI 2D Study Group, Frye RL, August P, Brooks MM, Hardison RM, Kelsey SF, MacGregor JM, Orchard TJ, Chaitman BR, Genuth SM, Goldberg SH, Hlatky MA, Jones TL, Molitch ME, Nesto RW, Sako EY, Sobel BE. A randomized trial of therapies for type 2 diabetes and coronary artery disease. N Engl J Med. 2009;360(24):2503-15.
6. Roger VL, Go AS, Lloyd-Jones DM, et al. Executive summary: heart disease and stroke statistics-2012 update: a report from the American Heart Association. Circulation. 2012;125:188-97.

7. Greenland P, Knoll MD, Stamler J, et al. Major risk factors as antecedents of fatal and nonfatal coronary heart disease events. JAMA. 2003;290:891-7.

8. Campeau L, Enjalbert M, Lespérance J, et al. The relation of risk factors to the development of atherosclerosis in saphenous-vein bypass grafts and the progression of disease in the native circulation. A study 10 years after aortocoronary bypass surgery. N Engl J Med. 1984;311:1329-32.

9. Loop FD, Lytle BW, Cosgrove DM, Stewart RW, Goormastic M, Williams GW, Golding LA, Gill CC, Taylor PC, Sheldon WC, et al. Influence of the internal-mammary-artery graft on 10-year survival and other cardiac events. $\mathrm{N}$ Engl $\mathrm{J}$ Med. 1986;314(1):1-6.

10. Fitzgibbon GM, Kafka HP, Leach AJ, Keon WJ, Hooper GD, Burton JR. Coronary bypass graft fate and patient outcome: angiographic follow-up of 5065 grafts related to survival and reoperation in 1388 patients during 25 years. J Am Coll Cardiol. 1996;28:616-26.

11. Alexander JH, Hafley G, Harrington RA, Peterson ED, Ferguson TB Jr, Lorenz TJ, Goyal A, Gibson M, Mack MJ, Gennevois D, Califf RM, Kouchoukos NT, PREVENT IV Investigators. Efficacy and safety of edifoligide, an E2F transcription factor decoy, for prevention of vein graft failure following coronary artery bypass graft surgery: PREVENT IV: a randomized controlled trial. JAMA. 2005;294(19):2446-54.

12. Bourassa MG, Fisher LD, Campeau L, Gillespie MJ, McConney $M$, Lesperance J. Long-term fate of bypass grafts: the coronary artery surgery study (CASS) and Montreal Heart Institute experiences. Circulation. 1985;72:V71-8.

13. Campeau L, Lesperance J, Hermann J, Corbara F, Grondin CM, Bourassa MG. Loss of the improvement of angina between 1 and 7 years after aortocoronary bypass surgery: correlations with changes in vein grafts and in coronary arteries. Circulation. 1979;60:1-5.

14. Taggart DP, Altman DG, Gray AM, Lees B, Nugara F, $\mathrm{Yu}$ LM, Campbell H, Flather M, ART Investigators. Randomized trial to compare bilateral vs. single internal mammary coronary artery bypass grafting: 1-year results of the Arterial Revascularisation Trial (ART). Eur Heart J. 2010;31(20):2470-81.

15. Muneretto C, Bisleri G, Negri A, Manfredi J, Metra M, Nodari S, Culot L, Dei Cas L. Total arterial 
myocardial revascularization with composite grafts improves results of coronary surgery in elderly: a prospective randomized comparison with conventional coronary artery bypass surgery. Circulation. 2003;108 Suppl 1:II29-33.

16. Locker C, Schaff HV, Dearani JA, Joyce LD, Park SJ, Burkhart HM, Suri RM, Greason KL, Stulak JM, Li Z, Daly RC. Multiple arterial grafts improve late survival of patients undergoing coronary artery bypass graft surgery: analysis of 8622 patients with multivessel disease. Circulation. 2012;126(9):1023-30.

17. Takagi H, Goto SN, Watanabe T, Mizuno Y, Kawai $\mathrm{N}$, Umemoto T. A meta-analysis of adjusted hazard ratios from 20 observational studies of bilateral versus single internal thoracic artery coronary artery bypass grafting. J Thorac Cardiovasc Surg. 2014;148(4):1282-90.

18. Weiss AJ, Zhao S, Tian DH, Taggart DP, Yan TD. A meta-analysis comparing bilateral internal mammary artery with left internal mammary artery for coronary artery bypass grafting. Ann Cardiothorac Surg. 2013;2(4):390-400.

19. Deo SV, Altarabsheh SE, Shah IK, Cho YH, McGraw M, Sarayyepoglu B, Medalion B, Markowitz AH, Park SJ. Are two really always better than one? Results, concerns and controversies in the use of bilateral internal thoracic arteries for coronary artery bypass grafting in the elderly: a systematic review and meta-analysis. Int J Surg. 2015;16:163-70.

20. Fleissner F, Engelke H, Rojas-Hernandez S, Ismail I, Stiefel P, Cebotari S, Haverich A, Shrestha M, Martens A. Long-term follow-up of total arterial revascularization with left internal thoracic artery and radial artery T-grafts: survival, cardiac morbidity and quality of life. Eur J Cardiothorac Surg. 2015;49(4):1195-200.

21. Deb S, Cohen EA, Singh SK, Une D, Laupacis A, Fremes SE, RAPS Investigators. Radial artery and saphenous vein patency more than 5 years after coronary artery bypass surgery: results from RAPS (Radial Artery Patency Study). J Am Coll Cardiol. 2012;60(1):28-35.

22. ElBardissi AW, Aranki SF, Sheng S, O’Brien SM, Greenberg CC, Gammie JS. Trends in isolated coronary artery bypass grafting: an analysis of the Society of Thoracic Surgeons adult cardiac surgery database. J Thorac Cardiovasc Surg. 2012;143(2):273-81.

23. Taggart DP, Altman DG, Gray AM, Lees B, Gerry S, Benedetto $U$, Flather M, ART Investigators. Randomized trial of bilateral versus single internal-thoracic-artery grafts. $\mathrm{N}$ Engl J Med. 2016;375(26):2540-9.
24. Lichtenwalter C, de Lemos JA, Roesle M, et al. Clinical presentation and angiographic characteristics of saphenous vein graft failure after stenting: insights from the SOS (stenting of saphenous vein grafts) trial. JACC Cardiovasc Interv. 2009;2:855-60.

25. Motwani JG, Topol EJ. Aortocoronary saphenous vein graft disease: pathogenesis, predisposition, and prevention. Circulation. 1998;97(9):916-31.

26. McGeachie JK, Meagher S, Prendergast FJ. Vein-to-artery grafts: the long-term development of neo-intimal hyperplasia and its relationship to vasa vasorum and sympathetic innervation. Aust N Z J Surg. 1989;59:59-65.

27. Angelini GD, Passani SL, Breckenridge IM, et al. Nature and pressure dependence of damage induced by distension of human saphenous vein coronary artery bypass grafts. Cardiovasc Res. 1987;21:902-7.

28. Kennedy JH, Lever MJ, Addis BJ, et al. Changes in vein interstitium following distension for aortocoronary bypass. J Cardiovasc Surg. 1989;30:992-5.

29. Li L, Terry CM, Shiu YT, Cheung AK. Neointimal hyperplasia associated with synthetic hemodialysis grafts. Kidney Int. 2008;74(10):1247-61.

30. Ishiwata S, Tukada T, Nakanishi S, et al. Postangioplasty restenosis: platelet activation and the coagulation-fibrinolysis system as possible factors in the pathogenesis of restenosis. Am Heart J. 1997;133:387-92.

31. Parang P, Arora R. Coronary vein graft disease: pathogenesis and prevention. Can J Cardiol. 2009;25(2):e57-62.

32. Chesebro JH, Fuster V, Elveback LR, Clements IP, Smith HC, Holmes DR Jr, Bardsley WT, Pluth JR, Wallace RB, Puga FJ, Orszulak TA, Piehler JM, Danielson GK, Schaff HV, Frye RL. Effect of dipyridamole and aspirin on late vein-graft patency after coronary bypass operations. N Engl J Med. 1984;310:209-14.

33. Allaire E, Clowes AW. Endothelial cell injury in cardiovascular surgery: the intimal hyperplastic response. Ann Thorac Surg. 1997;63(2):582-91.

34. Nwasokwa ON. Coronary artery bypass graft disease. Ann Intern Med. 1995;123:528-45.

35. Schwartz SM, Deblois D, O'Brien ER. The intima. Soil for atherosclerosis and restenosis. Circ Res. 1995;77:445-65.

36. Zhang L, Peppel K, Brian L, Chien L, Freedman NJ. Vein graft neointimal hyperplasia is exacerbated by tumor necrosis factor receptor-1 signaling in 
graft-intrinsic cells. Arterioscler Thromb Vasc Biol. 2004;24:2277-83.

37. Stary HC, Blankenhorn DH, Chandler AB, Glagov S, Insull W Jr, Richardson M, Rosenfeld ME, Schaffer SA, Schwartz CJ, Wagner WD. A definition of the intima of human arteries and of its atherosclerosis-prone regions. A report from the Committee on Vascular Lesions of the Council on Arteriosclerosis, American Heart Association. Circulation. 1992;85:391-405.

38. Hermiller JB, Tenaglia AN, Kisslo $\mathrm{KB}$, et al. In vivo validation of compensatory enlargement of atherosclerotic coronary arteries. Am J Cardiol. 1993;71:665-8.

39. Cameron AA, Green GE, Brogno DA, Thornton J. Internal thoracic artery grafts: 20-year clinical follow-up. J Am Coll Cardiol. 1995;25:188-92.

40. Hong YJ, Jeong MH, Ahn Y, Kang JC, Mintz GS, Kim $\mathrm{SW}$, et al. Impact of lesion location on intravascular ultrasound findings and short-term and five-year long-term clinical outcome after percutaneous coronary intervention for saphenous vein graft lesions. Int J Cardiol. 2013;167(1):29-33.

41. Sano K, Mintz GS, Carlier SG, Fujii K, Yasuda T, Kimura M, et al. Intravascular ultrasonic differences between aorto-ostial and shaft narrowing in saphenous veins used as aortocoronary bypass grafts. Am J Cardiol. 2006;97(10):1463-6.

42. Kennedy JW, Kaiser GC, Fisher LD, et al. Multivariatediscriminant analysis of the clinical and angiographic predictors of operative mortality from the Collaborative Study in Coronary Artery Surgery (CASS). J Thorac Cardiovasc Surg. 1980;80:876-87.

43. Yanagawa B, Algarni KD, Singh SK, et al. Clinical, biochemical, and genetic predictors of coronary arterybypass graft failure. J Thorac Cardiovasc Surg. 2014;148:515-20.

44. Debs S, Singh K, Tsubota H, et al. Influence of diabetes on long-term radial artery and saphenous vein graft patency after coronary artery bypass grafting surgery-a sub-study of the multi-centred radial artery patency study. http://aats.org/ annualmeeting/Program-Books/2014/L6.cgi.

45. Mehta RH, Honeycutt E, Shaw LK, Sketch MH Jr. Clinical characteristics associated with poor long-term survival among patients with diabetes mellitus undergoing saphenous vein graft interventions. Am Heart J. 2008;156(4):728-35.

46. Faulkner SL, Fisher RD, Conkle DM, Page DL, Bender HW Jr. Effect of blood flow rate on subendothelial proliferation in venous autografts used as arterial substitutes. Circulation. 1975;52(2 Suppl):I163-72.
47. Sabik JF III, Blackstone EH. Coronary artery bypass graft patency and competitive flow. J Am Coll Cardiol. 2008;51:126-8.

48. Sabik JF III, Lytle BW, Blackstone EH, Khan M, Houghtaling PL, Cosgrove DM. Does competitive flow reduce internal thoracic artery graft patency? Ann Thorac Surg. 2003;76:1490-7.

49. LoGerfo FW, Corson JD. Mannick JA Improved results with femoropopliteal vein grafts for limb salvage. Arch Surg. 1977;112(5):567-70.

50. Souza DS, Dashwood MR, Tsui JC, Filbey D, Bodin L, Johansson B, Borowiec J. Improved patency in vein grafts harvested with surrounding tissue: results of a randomized study using three harvesting techniques. Ann Thorac Surg. 2002;73(4):1189-95.

51. Souza DS, Johansson B, Bojö L, Karlsson R, Geijer H, Filbey D, Bodin L, Arbeus M, Dashwood MR. Harvesting the saphenous vein with surrounding tissue for CABG provides long-term graft patency comparable to the left internal thoracic artery: results of a randomized longitudinal trial. J Thorac Cardiovasc Surg. 2006;132(2):373-8.

52. Verma S, Lovren F, Pan Y, Yanagawa B, Deb S, Karkhanis R, Quan A, Teoh H, Feder-Elituv R, Moussa F, Souza DS, Fremes SE. Pedicled no-touch saphenous vein graft harvest limits vascular smooth muscle cell activation: the PATENT saphenous vein graft study. Eur J Cardiothorac Surg. 2014;45(4):717-25.

53. Samano N, Geijer H, Liden M, Fremes S, Bodin L, Souza D. The no-touch saphenous vein for coronary artery bypass grafting maintains a patency, after 16 years, comparable to the left internal thoracic artery: a randomized trial. J Thorac Cardiovasc Surg. 2015;150(4):880-8.

54. Nathoe HM, van Dijk D, Jansen EW, Octopus Study Group, et al. A comparison of on-pump and off-pump coronary bypass surgery in low-risk patients. N Engl J Med. 2003;348:394-402.

55. Puskas JD, Williams WH, Mahoney EM, et al. Off-pump vs conventional coronary artery bypass grafting: early and 1-year graft patency, cost, and quality-of-life outcomes: a randomized trial. JAMA. 2004;291:1841-9.

56. Straka Z, Widimsky P, Jirasek K, Stros P, Votava J, Vanek T, Brucek P, Kolesar M, Spacek R. Off-pump versus on-pump coronary surgery: final results from a prospective randomized study PRAGUE-4. Ann Thorac Surg. 2004;77(3):789-93.

57. Widimsky P, Straka Z, Stros P, et al. One-year coronary bypass graft patency: a randomized comparison between off-pump and on-pump surgery 
angiographic results of the PRAGUE-4 trial. Circulation. 2004;110:3418-23.

58. Hattler B, Messenger JC, Shroyer AL, Collins JF, Haugen SJ, Garcia JA, Baltz JH, Cleveland JC Jr, Novitzky D, Grover FL, Veterans Affairs Randomized On/Off Bypass (ROOBY) Study Group. Off-Pump coronary artery bypass surgery is associated with worse arterial and saphenous vein graft patency and less effective revascularization: results from the Veterans Affairs Randomized On/Off Bypass (ROOBY) trial. Circulation. 2012;125(23):2827-35.

59. Puskas JD, Williams WH, O'Donnell R, Patterson RE, Sigman SR, Smith AS, Baio KT, Kilgo PD, Guyton RA. Off-pump and on-pump coronary artery bypass grafting are associated with similar graft patency, myocardial ischemia, and freedom from reintervention: long-term follow-up of a randomized trial. Ann Thorac Surg. 2011;91(6):1836-42.

60. Sousa Uva M, Cavaco S, Oliveira AG, Matias F, Silva C, Mesquita A, Aguiar P, Bau J, Pedro A, Magalhães MP. Early graft patency after off-pump and on-pump coronary bypass surgery: a prospective randomized study. Eur Heart J. 2010;31(20):2492-9.

61. Takagi H, Matsui $M$, Umemoto $T$. Lower graft patency after off-pump than on-pump coronary artery bypass grafting: an updated meta-analysis of randomized trials. J Thorac Cardiovasc Surg. 2010;140(3):e45-7.

62. Zhang B, Zhou J, Li H, Liu Z, Chen A, Zhao Q. Comparison of graft patency between off-pump and on-pump coronary artery bypass grafting: an updated meta-analysis. Ann Thorac Surg. 2014;97(4):1335-41.

63. Flemma RJ, Johnson WD, Lepley D. Triple aorto-coronary vein bypass for coronary insufficiency. Arch Surg. 1971;103:82-3.

64. Bartley TD, Bigelow JC, Page US. Aortocoronary bypass grafting with multiple sequential anastomoses to a single vein. Arch Surg. 1972;105:915-7.

65. Sewell WH, Sewell KV. Technique for the coronary snake graft operation. Ann Thorac Surg. 1976;22:58-65.

66. Grondin CM, Limet R. Sequential anastomoses in coronary grafting: technical aspects and early and late angiographic results. Ann Thorac Surg. $1977 ; 23: 1-8$.

67. Sauvage LR, Wu HD, Kowalsky TE, Davis CC, Smith JC, Rittenhouse EA, et al. Healing basis and surgical techniques for complete revascularization of the left ventricle using only the internal mammary arteries. Ann Thorac Surg. 1986;42:449-65.
68. Mehta RH, Ferguson TB, Lopes RD, Hafley GE, Mack MJ, Kouchoukos NT, Gibson CM, Harrington RA, Califf RM, Peterson ED, Alexander JH. Saphenous vein grafts with multiple versus single distal targets in patients undergoing coronary artery bypass surgery: one-year graft failure and five-year outcomes from the Project of Ex-vivo Vein Graft Engineering via Transfection (PREVENT) IV Trial. Circulation. 2011;124:280-8.

69. Christenson JT, Simonet F, Schmuziger M. Sequential vein bypass grafting: tactics and long-term results. Cardiovasc Surg. 1998;6:389-97.

70. Oz BS, Iyem H, Akay HT, Bolcal C, Yokusoglu M, Kuralay E, Demirkilic U, Tatar H. Mid-term angiographic comparison of sequential and individual anatomosis techniques for diagonal artery. J Card Surg. 2006;21:471-4.

71. Zilla P, Human P, Wolf M, Lichtenberg W, Nasser R, Bezuidenhout D, Samodien N, Schmidt C, Franz T. Constrictive external nitinol meshes inhibit vein graft intimal hyperplasia in non-human primates. J Thorac Cardiovasc Surg. 2008;136:717-25.

72. Moodley L, Franz T, Human P, Wolf MF, Bezuidenhout D, Scherman J, Zilla P. Protective constriction of coronary vein grafts with knitted nitinol. Eur J Cardiothorac Surg. 2013;44:64-71.

73. Genoni M, Odavic D, Loblein H, Dzemali O. Use of the eSVS mesh: external vein support does not negatively impact early graft patency. Innovations (Philadelphia, Pa). 2013;8:211-4.

74. Klima U, Elsebay AA, Gantri MR, Bangardt J, Miller G, Emery RW. Computerized tomographic angiography in patients having eSVS mesh(R) supported coronary saphenous vein grafts: intermediate term results. J Cardiothorac Surg. 2014;9:138.

75. Inderbitzin DT, Bremerich J, Matt P, Grapow MT, Eckstein FS, Reuthebuch O. One-year patency control and risk analysis of eSVS ${ }^{\circledR}$-mesh-supported coronary saphenous vein grafts. J Cardiothorac Surg. 2015;10:108.

76. Nilsson T, Lagerqvist B, Tornvall P. Coronary angiography of patients with a previous coronary artery by-pass operation is associated with a three times increased risk for neurological complications. A report from the Swedish Coronary Angiography and Angioplasty Registry (SCAAR). Scand Cardiovasc J. 2009;43(6):374-9.

77. Anders K, Baum U, Schmid M, Ropers D, Schmid A, Pohle K, Daniel WG, Bautz W, Achenbach S. Coronary artery bypass graft (CABG) patency: assessment with high-resolution submillimeter 16-slice multidetector-row computed tomography (MDCT) 
versus coronary angiography. Eur J Radiol. 2006;57(3):336-44.

78. Achenbach S, Moshage W, Ropers D, Nossen J, Bachmann K. Noninvasive, three-dimensional visualization of coronary artery bypass grafts by electron beam tomography. Am J Cardiol. 1997;79:856e861.75.

79. Ropers D, Ulzheimer S, Wenkel E, et al. Investigation of aortocoronary artery bypass grafts by multislice spiral computed tomography with electrocardiographic-gated image reconstruction. Am J Cardiol. 2001;88:792e795.

80. Enzweiler CN, Wiese TH, Petersein J, et al. Diameter changes of occluded venous coronary artery bypass grafts in electron beam tomography: preliminary findings. Eur J Cardiothorac Surg. 2003;23:347e353.

81. Hamon M, Lepage O, Malagutti P, Riddell JW, Morello R, Agostini D, et al. Diagnostic performance of 16- and 64-section spiral CT for coronary artery bypass graft assessment: meta-analysis. Radiology. 2008;247(3):679-86.

82. Taylor AJ, Cerqueira M, Hodgson JM, Mark D, Min J, O'Gara P, et al. ACCF/SCCT/ACR/AHA/ASE/ASNC/ NASCI/SCAI/SCMR 2010 Appropriate Use Criteria for Cardiac Computed Tomography. A Report of the American College of Cardiology Foundation Appropriate Use Criteria Task Force, the Society of Cardiovascular Computed Tomography, the American College of Radiology, the American Heart Association, the American Society of Echocardiography, the American Society of Nuclear Cardiology, the North American Society for Cardiovascular Imaging, the Society for Cardiovascular Angiog. Circulation. 2010;122(21):e525-55.

83. von Kiedrowski H, Wiemer M, Franzke K, Preuss R, Vaske B, Butz T. Non-invasive coronary angiography: the clinical value of multi-slice computed tomography in the assessment of patients with prior coronary bypass surgery: evaluating grafts and native vessels. Int $\mathrm{J}$ Cardiovasc Imaging. 2009;25(2):161-70.

84. Englberger L, Streich M, Tevaearai H, Carrel TP. Different anticoagulation strategies in off-pump coronary artery bypass operations: a European survey. Interact Cardiovasc Thorac Surg. 2008;7:378-82.

85. Pantely GA, Goodnight SH Jr, Rahimtoola SH, et al. Failure of antiplatelet and anticoagulant therapy to improve patency of grafts after coronary-artery bypass: a controlled, randomized study. N Engl J Med. 1979;301:962-6.

86. McEnany MT, Salzman EW, Mundth ED, DeSanctis RW, Harthorne JW, Weintraub RM, Gates S, Austen
WG. The effect of antithrombotic therapy on patency rates of saphenous vein coronary artery bypass grafts. J Thorac Cardiovasc Surg. 1982;83(1):81-9.

87. Chesebro JH, Clements IP, Fuster V, Elveback LR, Smith HC, Bardsley WT, Frye RL, Holmes DR Jr, Vlietstra RE, Pluth JR, Wallace RB, Puga FJ, Orszulak TA, Piehler JM, Schaff HV, Danielson GK. A platelet inhibitor-drug trial in coronary-artery bypass operations: benefit of perioperative dipyridamole and aspirin therapy on early postoperative vein-graft patency. N Engl J Med. 1982;307:73-8.

88. Goldman S, Copeland J, Moritz T, et al. Improvement in early saphenous vein graft patency after coronary artery bypass surgery with antiplatelet therapy: results of a Veterans Administration Cooperative Study. Circulation. 1988;77:1324-32.

89. Bybee KA, Powell BD, Valeti U, et al. Preoperative aspirin therapy is associated with improved postoperative outcomes in patients undergoing coronary artery bypass grafting. Circulation. 2005;112:I286-92.

90. Mangano DT, Multicenter Study of Perioperative Ischemia Research Group. Aspirin and mortality from coronary bypass surgery. $\mathrm{N}$ Engl $\mathrm{J}$ Med. 2002;347:1309-17.

91. Dacey LJ, Munoz JJ, Johnson ER, et al. Effect of preoperative aspirin use on mortality in coronary artery bypass grafting patients. Ann Thorac Surg. 2000;70:1986-90.

92. Wijns W, Kolh P, Danchin N, et al. Guidelines on myocardial revascularization: the Task Force on Myocardial Revascularization of the European Society of Cardiology (ESC) and the European Association for Cardio-Thoracic Surgery (EACTS). Eur Heart J. 2010;31:2501-55.

93. Hillis LD, Smith PK, Anderson JL, et al. 2011 ACCF/ AHA Guideline for Coronary Artery Bypass Graft Surgery, A report of the American College of Cardiology Foundation/American Heart Association Task Force on Practice Guidelines. Developed in collaboration with the American Association for Thoracic Surgery, Society of Cardiovascular Anesthesiologists, and Society of Thoracic Surgeons. J Am Coll Cardiol. 2011;58:e123-210.

94. Fox KA, Anderson FA Jr, Dabbous OH, Steg PG, López-Sendón J, Van de Werf F, Budaj A, Gurfinkel EP, Goodman SG, Brieger D, GRACE investigators. Intervention in acute coronary syndromes: do patients undergo intervention on the basis of their risk characteristics? The Global Registry of Acute Coronary Events (GRACE). Heart. 2007;93(2):177-82. 
95. Ebrahimi R, Dyke C, Mehran R, et al. Outcomes following pre-operative clopidogrel administration in patients with acute coronary syndromes undergoing coronary artery bypass surgery: the ACUITY (Acute Catheterization and Urgent Intervention Triage strategY) trial. J Am Coll Cardiol. 2009;53:1965-72.

96. Biancari F, Airaksinen KE, Lip GY. Benefits and risks of using clopidogrel before coronary artery bypass surgery: systematic review and meta-analysis of randomized trials and observational studies. J Thorac Cardiovasc Surg. 2012;143(3):665-75.

97. Dunning J, Versteegh M, Fabbri A, Pavie A, Kolh P, Lockowandt U, Nashef SA. Guideline on antiplatelet and anticoagulation management in cardiac surgery. Eur J Cardiothorac Surg. 2008;34:73-92.

98. Eagle KA, Guyton RA, Davidoff R, Edwards FH, Ewy GA, Gardner TJ, Hart JC, Herrmann HC, Hillis LD, Hutter AM, et al. ACC/AHA 2004 guideline update for coronary artery bypass graft surgery: a report of the American College of Cardiology/American Heart Association Task Force on Practice Guidelines (Committee to Update the 1999 Guidelines for Coronary Artery Bypass Graft Surgery). Circulation. 2004;110:e340-437.

99. Fitchett D, Eikelboom J, Fremes S, Mazer D, Singh S, Bittira B, et al. Dual antiplatelet therapy in patients requiring urgent coronary artery bypass grafting surgery: a position statement of the Canadian Cardiovascular Society. Can J Cardiol. 2009;25:683-9.

100. Yusuf S, Zhao F, Mehta SR, Chrolavicius S, Tognoni $\mathrm{G}$, Fox KK, et al. Effects of clopidogrel in addition to aspirin in patients with acute coronary syndromes without ST-segment elevation. $N$ Engl J Med. 2001;345:494-502.

101. Wiviott SD, Braunwald E, McCabe CH, Montalescot G, Ruzyllo W, Gottlieb S, et al. Prasugrel versus clopidogrel with acute coronary syndromes. N Engl J Med. 2007;357:2001-15.

102. Wallentin L, Becker RC, Budaj A, Cannon CP, Emanuelsson $\mathrm{H}$, Held $\mathrm{C}$, et al. Ticagrelor versus clopidogrel in patients with acute coronary syndromes. N Engl J Med. 2009;361:1045-57.

103. Jneid H, Anderson JL, Wright RS, Adams CD, Bridges CR, Casey DE Jr, et al. ACCF/AHA focused update of the guideline for the management of patients with unstable angina/non-ST-elevation myocardial infarction (updating the 2007 guideline and replacing the 2011 focused update): a report of the American College of Cardiology Foundation/ American Heart Association Task Force on Practice Guidelines. J Am Coll Cardiol. 2012;60:645-81.
104. Tanguay JF, Bell AD, Ackman ML, Bauer RD, Cartier R, Chan WS, et al. Focused 2012 update of the Canadian Cardiovascular Society guidelines for the use of antiplatelet therapy. Can J Cardiol. 2013;29:1334-45.

105. Sibbald M, Yan AT, Huang W, Fox KA, Gore JM, Steg PG, Eagle KA, Brieger D, Montalescot G, Goodman SG. Association between smoking, outcomes, and early clopidogrel use in patients with acute coronary syndrome: insights from the Global Registry of Acute Coronary Events. Am Heart J. 2010;160(5):855-61.

106. Fox KA, Eagle KA, Gore JM, Steg PG, Anderson FA, GRACE and GRACE2 Investigators. The global registry of acute coronary events, 1999 to 2009GRACE. Heart. 2010;96(14):1095-101.

107. Hamm CW, Bassand JP, Agewall S, Bax J, Boersma E, Bueno $\mathrm{H}$, et al. ESC Guidelines for the management of acute coronary syndromes in patients presenting without persistent ST-segment elevation: the Task Force for the management of acute coronary syndromes (ACS) in patients presenting without persistent ST-segment elevation of the European Society of Cardiology (ESC). Eur Heart J. 2011;32:2999-3054.

108. Kulik A, Chan V, Ruel M. Antiplatelet therapy and coronary artery bypass graft surgery: perioperative safety and efficacy. Expert Opin Drug Saf. 2009;8(2):169-82.

109. Krimly A, Yan RT, Yan AT, DeYoung JP, Gallo R, Steg G, et al. Use of clopidogrel post-coronary artery bypass surgery in canadian patients with acute coronary syndromes. Can J Cardiol. 2011;27:711-5.

110. Rao RV, Goodman SG, Yan RT, Spencer FA, Fox KA, DeYoung JP, et al. Temporal trends and patterns of early clopidogrel use across the spectrum of acute coronary syndromes. Am Heart J. 2009;157:642-50.

111. Gao C, Ren C, Li D, Li L. Clopidogrel and aspirin versus clopidogrel alone on graft patency after coronary artery bypass grafting. Ann Thorac Surg. 2009;88:59-62.

112. Sun JC, et al. Randomized trial of aspirin and clopidogrel versus aspirin alone for the prevention of coronary artery bypass graft occlusion: the Preoperative Aspirin and Postoperative Antiplatelets in Coronary Artery Bypass Grafting study. Am Heart J. 2010;160:1178-84.

113. Gao G, Zheng Z, Pi Y, Lu B, Lu J, Hu S. Aspirin plus clopidogrel therapy increases early venous graft patency after coronary artery bypass surgery a single-center, randomized, controlled trial. J Am Coll Cardiol. 2010;56(20):1639-43. 
114. Kulik A, Le May MR, Voisine P, Tardif JC, Delarochelliere R, Naidoo S, Wells GA, Mesana TG, Ruel M. Aspirin plus clopidogrel versus aspirin alone after coronary artery bypass grafting: the Clopidogrel After Surgery For Coronary Artery Disease (CASCADE) Trial. Circulation. 2010;122:2680-7.

115. Mannacio VA, Di Tommaso L, Antignan A, De Amicis V, Vosa C. Aspirin plus clopidogrel for optimal platelet inhibition following off-pump coronary artery bypass surgery: results from the CRYSSA (prevention of Coronary arteRY bypaSS occlusion After off-pump procedures) randomised study. Heart. 2012;98(23):1710-5.

116. Rafiq S, Johansson P, Kofoed K, et al. Thrombelastographic hypercoagulability and antiplatelet therapy after coronary artery bypass surgery (TEG-CABG trial): a randomized controlled trial. Platelets. 2017;22:1-8.

117. Kulik A, Ruel M, Jneid H, et al. Secondary prevention after coronary artery bypass surgery-a scientific statement from the American Heart Association. Circulation. 2015;131:927-64.

118. Biancari F, Myllylä M, Lepojärvi S, Kuttila K, Porela P, Laitio T, Ylitalo A, Jokinen V, Luokkala A, Airaksinen KE. Preoperative warfarin treatment and outcome of coronary artery bypass graft surgery. Ann Thorac Surg. 2010;89(4):1139-45.

119. Hata M, Akiyama K, Wakui S, Takasaka A, Sezai A, Shiono M. Does warfarin help prevent ischemic stroke in patients presenting with post coronary bypass paroxysmal atrial fibrillation? Ann Thorac Cardiovasc Surg. 2013;19(3):207-11.

120. Fremes SE, et al. Optimal antithrombotic therapy following aortocoronary bypass: a meta-analysis. Eur J Cardiothorac Surg. 1993;7:169-80.

121. Yamaguchi A, Kitamura N, Miki T, Tatebayashi T, Kawashima M, Otaki M, Tamura H. Comparative study of anticoagulant management after coronary artery bypass surgery-warfarin versus dipyridamole. Nihon Kyobu Geka Gakkai Zasshi. 1992;40(4):485-9.

122. van der Meer J, Hillege HL, Kootstra GJ. Prevention of one-year vein-graft occlusion after aortocoronary-bypass surgery: a comparison of low-dose aspirin, low-dose aspirin plus dipyridamole, and oral anticoagulants. The CABADAS Research Group of the Interuniversity Cardiology Institute of The Netherlands. Lancet. 1993;342:257-64.

123. Gohlke H, Gohlke-Barwolf C, Sturzenhofecker P, et al. Improved graft patency with anticoagulant therapy after aortocoronary bypass surgery: a prospective, randomized study. Circulation. 1981;64(2 Pt 2):II22-7.

124. Investigators The Post Coronary Artery Bypass Graft Trial. The effect of aggressive lowering of low-density lipoprotein cholesterol levels and low-dose anticoagulation on obstructive changes in saphenous-vein coronary-artery bypass grafts. N Engl J Med. 1997;336:153-62.

125. Huynh T, Théroux P, Bogaty P, Nasmith J, Solymoss S. Aspirin, warfarin, or the combination for secondary prevention of coronary events in patients with acute coronary syndromes and prior coronary artery bypass surgery. Circulation. 2001;103(25):3069-74.

126. Smith PK, Goodnough LT, Levy JH, Poston RS, Short MA, Weerakkody GJ, Lenarz LA. Mortality benefit with prasugrel in the TRITON-TIMI 38 coronary artery bypass grafting cohort: risk-adjusted retrospective data analysis. J Am Coll Cardiol. 2012;60(5):388-96.

127. Held C, Asenblad N, Bassand JP, Becker RC, Cannon CP, Claeys MJ, Harrington RA, Horrow J, Husted S, James SK, Mahaffey KW, Nicolau JC, Scirica BM, Storey RF, Vintila M, Ycas J, Wallentin L. Ticagrelor versus clopidogrel in patients with acute coronary syndromes undergoing coronary artery bypass surgery: results from the PLATO (Platelet Inhibition and Patient Outcomes) trial. J Am Coll Cardiol. 2011;57(6):672-84.

128. Brilakis ES, Held C, Meier B, Cools F, Claeys MJ, Cornel JH, Aylward P, Lewis BS, Weaver D, Brandrup-Wognsen G, Stevens SR, Himmelmann A, Wallentin L, James SK. Effect of ticagrelor on the outcomes of patients with prior coronary artery bypass graft surgery: insights from the PLATelet inhibition and patient outcomes (PLATO) trial. Am Heart J. 2013;166(3):474-80.

129. Hansson EC, Jidéus L, Åberg B, Bjursten H, Dreifaldt M, Holmgren A, Ivert T, Nozohoor S, Barbu M, Svedjeholm R, Jeppsson A. Coronary artery bypass grafting-related bleeding complications in patients treated with ticagrelor or clopidogrel: a nationwide study. Eur Heart J. 2016;37(2):189-97.

130. Knatterud GL, Rosenberg Y, Campeau L, Geller NL, Hunninghake DB, Forman SA, Forrester JS, Gobel FL, Herd JA, Hickey A, Hoogwerf BJ, Terrin ML, White C. Long-term effects on clinical outcomes of aggressive lowering of low-density lipoprotein cholesterol levels and low-dose anticoagulation in the Post Coronary Artery Bypass Graft Trial: Post CABG Investigators. Circulation. 2000;102:157-65.

131. Makuuchi H, Furuse A, Endo M, et al. Effect of pravastatin on progression of coronary 
atherosclerosis in patients after coronary artery bypass surgery. Circ J. 2005;69:636-43.

132. Kulik A, Voisine P, Mathieu P, Masters RG, Mesana TG, Le May MR, Ruel M. Statin therapy and saphenous vein graft disease after coronary bypass surgery: analysis from the CASCADE randomized trial. Ann Thorac Surg. 2011;92(4):1284-90.

133. Kang S, Liu Y, Liu XB. Effects of aggressive statin therapy on patients with coronary saphenous vein bypass grafts: a systematic review and meta-analysis of randomized, controlled trials. Clin Ther. 2013;35(8):1125-36.

134. Frick MH, Syvanne M, Nieminen MS, et al. Prevention of the angiographic progression of coronary and vein-graft atherosclerosis by gemfibrozil after coronary bypass surgery in men with low levels of HDL cholesterol. Lopid Coronary Angiography Trial (LOCAT) study group. Circulation. 1997;96:2137-43.

135. Blankenhorn DH, Johnson RL, Nessim SA, Azen SP, Sanmarco ME, Selzer RH. The cholesterol lowering atherosclerosis study (CLAS): design, methods, and baseline results. Control Clin Trials. 1987;8:356-87.

136. Cashin-Hemphill L, Mack WJ, Pogoda JM, Sanmarco ME, Azen SP, Blankenhorn DH. Beneficial effects of colestipol-niacin on coronary atherosclerosis. A 4-year follow-up. JAMA. 1990;264:3013-7.

137. Azen SP, Mack WJ, Cashin-Hemphill L, et al. Progression of coronary artery disease predicts clinical coronary events. Long-term follow-up from the cholesterol lowering atherosclerosis study. Circulation. 1996;93:34-41.

138. Zhou Q, Liao JK. Statins and cardiovascular diseases: from cholesterol lowering to pleiotropy. Curr Pharm Des. 2009;15:467-78.

139. Veillard NR, Braunersreuther V, Arnaud C, et al. Simvastatin modulates chemokine and chemokine receptor expression by geranylgeranyl isoprenoid pathway in human endothelial cells and macrophages. Atherosclerosis. 2006;188:51-8.

140. Barakat A, Saad M, Abuzaid A, et al. Perioperative statin therapy for patients undergoing coronary artery bypass grafting. Ann Thorac Surg. 2016;101:818-25.

141. Hillis LD, Smith PK, Anderson JL, Bittl JA, Bridges CR, Byrne JG, Cigarroa JE, DiSesa VJ, Hiratzka LF, Hutter AM Jr, Jessen ME, Keeley EC, Lahey SJ, Lange RA, London MJ, Mack MJ, Patel MR, Puskas JD, Sabik JF, Selnes O, Shahian DM, Trost JC, Winniford MD, Jacobs AK, Anderson JL, Albert N, Creager MA, Ettinger SM, Guyton RA, Halperin JL, Hochman JS, Kushner FG, Ohman EM, Stevenson W, Yancy CW,
American College of Cardiology Foundation/American Heart Association Task Force on Practice Guidelines. 2011 ACCF/AHA guideline for coronary artery bypass graft surgery: executive summary: a report of the American College of Cardiology Foundation/American Heart Association Task Force on Practice Guidelines. J Thorac Cardiovasc Surg. 2012;143(1):4-34.

142. Southerland KW, Frazier SB, Bowles DE, Milano CA, Kontos CD. Gene therapy for the prevention of vein graft disease. Transl Res. 2013;161(4):321-38.

143. Grube E, Felderhoff T, Fitzgerald $\mathrm{P}$, et al. Late-breaking clinical trial abstracts. Circulation. 2001;104:1b-4b.

144. Alexander JH, Hafley G, Harrington RA, PREVENT IV Investigators, et al. Efficacy and safety of edifoligide, an E2F transcription factor decoy, for prevention of vein graft failure following coronary artery bypass graft surgery: PREVENT IV: a randomized controlled trial. JAMA. 2005;294:2446-54.

145. Brilakis ES, Ty Wang, Rao SV, et al. Frequency and predictors of drug-eluting stent use in saphenous vein bypass graft percutaneous coronary interventions: a report from the American College of Cardiology National Cardiovascular Data CathPCI registry. JACC Cardiovasc Interv. 2010;3(10):1068-73.

146. Marmagkiolis K, Grines C, Bilodeau L. Current percutaneous treatment strategies for saphenous vein graft disease. Catheter Cardiovasc Interv. 2013;82(3):406-13.

147. Savage MP, Douglas JS Jr, Fischman DL, et al. Stent placement compared with balloon angioplasty for obstructed coronary bypass grafts. Saphenous Vein De Novo Trial Investigators. $\mathrm{N}$ Engl $\mathrm{J}$ Med. 1997;337:740-7.

148. Hanekamp CE, Koolen JJ, Den Heijer P, Schalij MJ, Piek JJ, Bar FW, De Scheerder I, Bonnier HJ, Pijls NH. Randomized study to compare balloon angioplasty and elective stent implantation in venous bypass grafts: the Venestent study. Catheter Cardiovasc Interv. 2003;60:452-7.

149. Vermeersch P, Agostoni P, Verheye S, et al. Randomized double-blind comparison of sirolimus-eluting stent versus bare-metal stent implantation in diseased saphenous vein grafts: six-month angiographic, intravascular ultrasound, and clinical follow-up of the RRISC Trial. J Am Coll Cardiol. 2006;48:2423-31.

150. Brilakis ES, Lichtenwalter C, de Lemos JA, Roesle M, Obel O, Haagen D, Saeed B, Gadiparthi C, Bissett JK, Sachdeva R, Voudris VV, Karyofillis P, Kar B, Rossen J, Fasseas P, Berger P, Banerjee S. A randomized 
controlled trial of a paclitaxel-eluting stent versus a similar bare-metal stent in saphenous vein graft lesions the SOS (stenting of saphenous vein grafts) trial. J Am Coll Cardiol. 2009;53(11):919-28.

151. Mehilli J, Pache J, Abdel-Wahab M, et al. Drug-eluting versus bare-metal stents in saphenous vein graft lesions (ISAR-CABG): a randomised controlled superiority trial. Lancet. 2011;378:1071-8.

152. Meier P, Brilakis ES, Corti R, Knapp G, Shishehbor $\mathrm{MH}$, Gurm HS. Drug-eluting versus bare-metal stent for treatment of saphenous vein grafts: a meta-analysis. PLoS One. 2010;5:e11040.

153. Testa L, Agostoni P, Vermeersch P, et al. Drug eluting stents versus bare metal stents in the treatment of saphenous vein graft disease: a systematic review and meta-analysis. EuroIntervention. 2010;6:527-36.

154. Lee MS, $\mathrm{Hu} \mathrm{PP}$, Aragon J, et al. Comparison of sirolimus-eluting stents with paclitaxel-eluting stents in saphenous vein graft intervention (from a multicenter Southern California Registry). Am J Cardiol. 2010;106:337-41.

155. Hougaard M, Thayssen P, Kaltoft A, Tilsted HH, Maeng M, Lassen JF, Thuesen L, Okkels Jensen L. Long-term outcome following percutaneous coronary intervention with drug-eluting stents compared with bare-metal stents in saphenous vein graft lesions: from Western Denmark Heart Registry. Catheter Cardiovasc Interv. 2014;83(7):1035-42.

156. Kitabata H, Loh JP, Pendyala LK, Badr S, Dvir D, Barbash IM, Minha S, Torguson R, Chen F, Satler LF, Suddath WO, Kent KM, Pichard AD, Waksman R. Two-year follow-up of outcomes of second-generation everolimus-eluting stents versus first-generation drug-eluting stents for stenosis of saphenous vein grafts used as aortocoronary conduits. Am J Cardiol. 2013;112(1):61-7.

157. Pokala NR, Menon RV, Patel SM, Christopoulos G, Christakopoulos GE, Kotsia AP, Rangan BV, Roesle M, Abdullah S, Grodin J, Kumbhani DJ, Hastings J, Banerjee S, Brilakis ES. Long-term outcomes with first- vs. second-generation drug-eluting stents in saphenous vein graft lesions. Catheter Cardiovasc Interv. 2016;87(1):34-40.

158. Costopoulos C, Latib A, Naganuma T, Sticchi A, Chieffo A, Figini F, Carlino M, Montorfano M, Naim C, Kawaguchi M, Giannini F, Colombo A. Comparison of first- and second-generation drug-eluting stents in saphenous vein grafts used as aorto-coronary conduits. Am J Cardiol. 2013;112(3):318-22.

159. Yaku H, Doi K. Redo coronary artery bypass grafting. Gen Thorac Cardiovasc Surg. 2014;62(8):453-60.
160. Stamou SC, Pfister AJ, Dullum MK, et al. Late outcome of reoperative coronary re-vascularization on the beating heart. Heart Surg Forum. 2001;4:69-73.

161. Christenson JT, Schmuziger M, Simonet F. Reoperative coronary artery bypass procedures: risk factors for early mortality and late survival. Eur J Cardiothorac Surg. 1997;11:129-33.

162. Labinaz M, Kilaru R, Pieper K, et al. Outcomes of patients with acute coronary syndromes and prior coronary artery bypass grafting: results from the platelet glycoprotein IIb/IIIa in unstable angina: receptor suppression using integrilin therapy (PURSUIT) trial. Circulation. 2002;105:322-7.

163. Labinaz M, Sketch MH Jr, Ellis SG, et al. Outcome of acute ST-segment elevation myocardial infarction in patients with prior coronary artery bypass surgery receiving thrombolytic therapy. Am Heart J. 2001;141:469-77.

164. Nikolsky E, McLaurin BT, Cox DA, et al. Outcomes of patients with prior coronary artery bypass grafting and acute coronary syndromes: analysis from the ACUITY (Acute Catheterization and Urgent Intervention Triage Strategy) trial. JACC Cardiovasc Interv. 2012;5:919-26.

165. Gurfinkel EP, de la Perez HR, Brito VM, et al. Invasive vs non-invasive treatment in acute coronary syndromes and prior bypass surgery. Int J Cardiol. 2007;119:65-72.

166. Held C, Tornvall P, Stenestrand U. Effects of revascularization within 14 days of hospital admission due to acute coronary syndrome on 1-year mortality in patients with previous coronary artery bypass graft surgery. Eur Heart J. 2007;28:316-25.

167. Stephan WJ, O'Keefe JH Jr, Piehler JM, et al. Coronary angioplasty versus repeat coronary artery bypass grafting for patients with previous bypass surgery. J Am Coll Cardiol. 1996;28:1140-6.

168. Morrison DA, Sethi G, Sacks J, Henderson W, Grover $\mathrm{F}$, Sedlis $\mathrm{S}$, Esposito R, Ramanathan $\mathrm{K}$, Weiman D, Saucedo J, Antakli T, Pramesh V, Pett S, Vernon S, Birjiniuk V, Welt F, Krucoff M, Wolfe W, Lucke JC, Mediratta S, Booth D, Barbiere C, Lewis D. Percutaneous coronary intervention versus coronary artery bypass graft surgery for patients with medically refractory myocardial ischemia and risk factors for adverse outcomes with bypass: a multicenter randomized trial. Investigators of the Department of Veterans Affairs Cooperative Study \#385, the Angina With Extremely Serious Operative Mortality Evaluation (AWESOME). J Am Coll Cardiol. 2001;38(143-9):8.

169. Morrison DA, Sethi G, Sacks J, Henderson WG, Grover F, Sedlis S, Esposito R. Percutaneous 
coronary intervention versus repeat bypass surgery for patients with medically refractory myocardial ischemia: AWESOME randomized trial and registry experience with post-CABG patients. J Am Coll Cardiol. 2002;40:1951-4.

170. Brener SJ, Lytle BW, Casserly IP, Ellis SG, Topol EJ, Lauer MS. Predictors of revascularization method and long-term outcome of percutaneous coronary intervention or repeat coronary bypass surgery in patients with multivessel coronary disease and previous coronary bypass surgery. Eur Heart J. 2006;27:413-8.

171. Cole JH, Jones EL, Craver JM, et al. Outcomes of repeat revascularization in diabetic patients with prior coronary surgery. J Am Coll Cardiol. 2002;40:1968-75.
172. Harskamp RE, Beijk MA, Damman P, et al. Clinical outcome after surgical or percutaneous revascularization in coronary bypass graft failure. J Cardiovasc Med. 2013;14(6):438-45.

173. Byrne J, Leacche M, Vaughan D, et al. Hybrid cardiovascular procedures. JACC Card Int. 2008;1:459-68.

174. Gilard M, Bezon E, Cornily JC, et al. Same-day combined percutaneous coronary intervention and coronary artery surgery. Cardiology. 2007;108:363-7.

175. Holzhey DM, Jacobs S, Mochalski M, et al. Minimally invasive hybrid coronary artery revascularization. Ann Thorac Surg. 2008;86:1856-60. 